\title{
The management of African asylum seekers and the imaginary of the border in Israel
}

\author{
Sharon Weinblum
}

I

N 2005, SUDANESE men, women, and children, adopting the same route that smugglers and traffickers had used for decades, started crossing the Egyptian border to ask for refuge in Israel. In 2014, around 47,000 individuals who had taken the same path were present on Israeli territory, among whom were 8,852 Sudanese nationals and 34,475 Eritreans (Shani et al. 2014). While first depicted as survivors of genocide entitled to claim protection (Anteby-Yemini 2009; Willen 2010; Paz 2011), African asylum seekers ${ }^{1}$ soon entered into a language of insecurity and criminality in the Israeli political discourse. The crossing of the Egyptian-Israeli border and the settling of asylum seekers in Israeli cities (in particular Tel Aviv and Eilat) became a matter of concern, and technologies blocking the incorporation of these non-Jewish migrants into Israel and its territory were deployed. These technologies included the refusal, until 2013, to examine individual asylum requests, the construction of a fence at the Israeli-Egyptian border, the amendment of a law criminalising the 'infiltration' of the Egyptian border by migrants, the use of detention against asylum seekers, and the 2012 and 2015 decisions to return African migrants to their country of origin or to third countries.

Against this backdrop, this chapter focuses on the legitimisation of these technologies of blocking and exclusion in the Israeli political discourse. More specifically, through a discourse analysis of political actors' public speeches and parliamentary debates, I seek to answer the following questions: how have exclusionary policies been justified in the Israeli political discourse? To which other elements have the mobility of asylum seekers and the policies in place been connected in political discourse and with what effects? How has the imaginary of the border, detention, and deportation played out in the discourse surrounding the issue of asylum seekers? By its approach, this contribution is in line with the substantial scholarship that has studied the construction of migrants in public discourses (Huysmans 2006; Walters 2008; Squire 2009). However, this chapter does not only explore how migrants are constructed in discourse but also 
how the exclusionary techniques in place, including the building of the fence at the border, and the resort to detention and expulsion, are entangled in broader narratives on mobility, security, sovereignty, and the regime boundaries in Israel. By its object, this chapter is thus also complementary to the important set of studies focused on the border-mobility nexus. However, while these studies have mostly addressed the border either through the prism of exception (Doty 2003; Jones 2009; Salter 2008) or through a Foucauldian lens focused on discipline and control (Walters 2006), this chapter does not specifically ask what role the border plays, whether as a means of demarcation or in its 'liquid' form. Rather, it explores the imaginary of border protection (along with other technologies) as articulated in discourse and investigates to what extent this imaginary contributes to a broader discourse sustaining the exclusionary asylum policies in place.

The discourse analysis of political actors' speeches and debates indicates that Israeli exclusionary policies of asylum have been justified through very 'classical' securitising storylines where asylum seekers are constructed in three ways: as a threat to national security, as a disruption of social order, and as a threat to national identity. The analysis of political discourse also shows that in these storylines, detention and expulsion but, more significantly, the imaginary of the border as a protective shield, have played a significant role. From this perspective, the chapter moves away from the growing claim that the border should be studied as a liquid, dislocated site of control (Bigo and Guild 2010; Bigo 2014). ${ }^{2}$ The chapter argues instead that in spite of the modernisation of border technologies and the conceptualisation of 'smart borders' (including in Israel), the regulation of the mobility of non-authorised migrants continues to be articulated in classical securitising frames where the border is presented as a line of demarcation protecting us from an other.

The first part of this chapter offers an overview of mobility control in Israel and of the management of African asylum seekers since their arrival in Israel in 2005. In the second part, this chapter investigates the discourses underpinning the asylum policies in place in Israel and discusses the effects of these discourses.

\section{Mobility, sovereignty, and regime boundaries in Israel}

Promoting the mobility of some while monitoring that of undesired others has been central to the Israeli regime, its security practices, and the protection of its regime boundaries. In terms of regime boundaries, the 'ascent' (aliyah) of Jews from the diaspora to 'Eretz Israel' (the land of Israel) was at the core of the Zionist project according to which 'similar progression of immigration and colonization was the precondition for the coming into existence of the State of Israel in 1948' (Shafir 1984: 803). The Law of Return (1950), passed two years after the establishment of the state prolonged this approach by giving Israel a jus sanguinis model of immigration. The Law of Return provides that any Jewish persons and 
their descendants may immigrate to Israel and be granted the status of oleh (i.e., the one who ascends) thus becoming Israeli nationals (Law on Citizenship 1952). In contrast, naturalisation procedures for non-Jews are rare and mostly confined to spouses of Israelis. As a consequence, the vast majority of immigrants who settle in Israel are Jews from abroad legally seen as 'returning' to Israel. The nature of immigration shifted slightly after the 1990s, when the Israeli government started calling temporary non-Jewish migrant workers to Israel. ${ }^{3}$ However, despite the significant number of migrant workers who reside in Israel (around 100,000 undocumented migrant workers for around 70,000 migrant workers with documents ${ }^{4}$ ), and the growing number of migrant workers' children born and raised in the country, the government considers these migrants as temporarily authorised workers meant to remain at the margin of the polity and to leave the country after a fixed period of time (Kemp 2010). As such, they have no entitlement to apply either for citizenship or for permanent residency.

Aside from an immigration regime promoting the establishment of those inside the ethnos and excluding those defined otherwise, the Israeli government has put in place a series of policies meant to control and monitor 'dangerous mobilities' (Walters 2006: 199). Four years after the passing of the Law of Return, parliament passed the Prevention of Infiltration Law (1954), the purpose of which was to prevent potential guerrilla fighters within the Palestinian refugee population re-entering the territory. ${ }^{5}$ The law more precisely provided that anyone entering Israel from a neighbouring state via a non-official entry point would be defined as an 'infiltrator' and could be subject to a punishment of five to fifteen years in prison (Prevention of Infiltration Law 1954). Concurrently, Palestinians who had remained in the country during the 1948 war and later became Israeli citizens were the subject of strong controls during the first years of the state's existence. From 1948 to 1965, the majority of Palestinian citizens living in Israel were put under military administration, which enabled the Israeli military to restrict this population's freedom considerably, including its freedom of movement (Lustick 1980). Almost seventy years later, 'biopolitical practices of mobility regulation' (Parsons and Salter 2008: 702) still epitomise the concern for mobility control and blocking in Israel. The screening of travellers and commuters at the airport, at the territorial border, or at train stations are ingrained daily practices, walls are part of the landscape (including the "barrier of separation', geder hafrada, around the West Bank and the fence at the Egyptian border $)^{6}$ and the use of checkpoints to select those who are allowed to leave or move within the Occupied Territories are at the centre of the Israeli regime of occupation (Parsons and Salter 2008; Kotef and Amir 2011).

The modalities adopted by the Israeli authorities to deal with the border crossing of non-Jewish African asylum seekers and their presence in the country have to a large extent been a continuity of these practices of control, exclusion, and blocking. Exclusion first resulted in the absence, and later in the closed character, 
of the Israeli asylum regime. In spite of the fact that Israel is a signatory to the 1951 Refugee Convention, the country has never incorporated the international convention in its national legislation. The granting of residency to boat people at the end of the 1970s and the temporary protection of Bosnians and Kosovars in the 1990s were the result of ad hoc government decisions that did not lead to the adoption of any asylum legislation (Yaron et al. 2013). In this context, the management of African asylum seekers as of 2005 was characterised by improvisation or, to use Yonathan Paz's (2011) words, by an 'ordered disorder'. ${ }^{7}$

In 2007, the Israeli government decided that 492 Darfuris, considered genocide survivors, would be granted temporary residence and working permits in Israel (Anteby-Yemini 2009; Willen 2010). For the other Sudanese and Eritreans who arrived in the following years, the asylum system was closed, however, asylum seekers being barred from submitting asylum requests altogether. Instead, asylum seekers from Eritrea and Sudan were granted temporary permits guaranteeing momentary protection from deportation. These permits, which must be renewed every two months at the Ministry of the Interior, allow Eritreans and Sudanese migrants to temporarily stay in Israel until the government deems it safe to return them to their country of origin. While allowing asylum seekers to temporarily remain on the territory, the permits nevertheless provide very limited access to health care (including for children) and to welfare services and explicitly mention that they do not constitute a working permit (although in practice, the work prohibition has been unenforced after Supreme Court ruling HCJ 6312/10 in 2011). In 2013, after pressure from the Supreme Court, the government agreed to start assessing individual asylum requests for the first time. However, by February 2015 around 5,300 asylum requests had been submitted, among which just 1,050 had been processed and only four had led to the granting of refugee status (Lior 2015). ${ }^{8}$

Besides the slow and dissuasive refugee status determination procedure, the government has put in place a series of policies aimed at regulating the movement of asylum seekers, encouraging the departure of those already in Israel, and blocking the arrival of those attempting to come. Among the tools employed, the government has used detention to varying degrees. After 2005, many African asylum seekers were arrested upon their arrival and detained in prisons located at the Egyptian border. While in detention, asylum seekers received medical examinations, their state of origin would be checked and they would be registered in a database - yet no asylum request would be taken. After a variable period of time (from a few weeks to a few months), some of these detainees were relocated in 'alternative detention' in kibbutzim and moshavim (collective farms) (Refugees' Rights Forum 2008). ${ }^{9}$ Later on, those leaving detention were taken directly to cities, mainly to Tel Aviv, where most asylum seekers currently live. ${ }^{10}$

While detention was used in a non-systematic way in the early years, the 2012 amendment to the Prevention of Infiltration Law, which criminalised 
migrants crossing the border without authorisation, formally introduced detention into the government toolkit. According to the 2012 amendment, any person (and his or her children) crossing the Egyptian border illegally was to be considered an 'infiltrator' and thereby subject to a three-year period of imprisonment without trial. For 'infiltrators' coming from an 'enemy state', namely Sudan, detention could be indefinite. In September 2013 the Supreme Court cancelled the amendment on the ground that it infringed some of the rights human dignity and liberty - guaranteed by the Israeli Basic Law in a disproportionate way (HCJ 7146/12). Thereafter, the government introduced a new amendment to the Prevention of Infiltration Law providing that those crossing the border illegally would be held in prison for a maximum period of one year (in the prison of Saharonim located in the desert), while those already in the country and who could not be returned would be placed in open detention centres (Holot, located next to Saharonim) for an indefinite period of time (Prevention of Infiltration Law, Amendment 4, 2013). In mid-June 2014, about 2,500 asylum seekers were detained in Holot or Saharonim (according to Human Rights Watch 2014), and in September of the same year, the Supreme Court once again cancelled the amendment on similar grounds as in 2013 (HCJ 8425/13). In response to the ruling, the Knesset passed Amendment 5 of the Prevention of Infiltration Law, which turned the one-year period of prison into three months and the indefinite detention in open facilities into twenty months. ${ }^{11}$ In 2015 , the Supreme Court examined the law again and ruled that asylum seekers detained for more than one year should be released. However, it did not condemn the resort to detention in general (HCJ 8665/2014).

In parallel with, or as a complementary tool to detention, the government started making use of expulsion and 'voluntary return'12 after 2012. Among those who were coercively or voluntarily returned were South Sudanese who lost their temporary protection in 2012 on the ground that South Sudan was considered a safe place by the government. Following this government decision, more than 1,300 South Sudanese were returned to the newly independent state (Lijnders 2013). Other asylum seekers from Eritrea and Sudan detained in Holot and in the prison of Saharonim were also encouraged to 'voluntarily return' to their countries or to third countries during the same period and in 2015, non-governmental organisations estimated that around 9,000 asylum seekers had left Israel (Drori-Avraham et al. 2015). In April 2015, the government announced its decision to expel all remaining asylum seekers from Eritrea and Sudan to third countries (known to be Rwanda and possibly Uganda), where they would allegedly receive a status. The decision has not been implemented at the time of writing.

Finally, concurrently to the other policies in place, the government worked on making it harder to cross the border. In the early years, soldiers patrolling at the Egypt-Israel border were encouraged to make use of 'hot returns', that is, to 
directly return to Egypt the individuals attempting to cross the border. Later on, in 2010, the government announced its decision to build a wall along the entire Israel-Egypt border. The 240-kilometre barrier was completed in 2013, and since then only a few African asylum seekers have succeeded in crossing the border.

The next part of this chapter explores how these techniques of control, exclusion, and blocking used to deal with African asylum seekers were justified in the Israeli political discourse and with what effects.

\section{The construction of the threatening other and the imaginary of the border}

Drawing on discourse theory and discourse analysis, the second part of this contribution explores the way Israeli policies of asylum have been articulated and justified in political discourse. More specifically, the next part disentangles the political discourse justifying the asylum policies by identifying two elements of the political discourse. On the one hand, I identify the main storylines present in the discourse, i.e., the main condensed statements 'summarising complex narratives, used by people as "short hand" in discussions' (Hajer 2006: 69). On the other hand, I unpack the chains of equivalence and opposition (Saussure 2002) through which migrants and the technologies of exclusion are articulated and given meaning. The discourses under study are official speeches by ministers and parliamentary debates since 2007, including the debates held in the Knesset over the three amendments of the Prevention of Infiltration Law (2012, 2013, 2014). The analysis displays that the political discourse justifying asylum policies has entailed three different storylines, which have constructed asylum seekers as a threat to national security, as disruptive of social order, and as a threat to national identity. It shows that in all storylines the notions of the border and border reinforcement have been central.

\section{African migrants as 'infiltrators' and the border as a shield against existential threat}

The first central storyline of the political discourse associates African asylum seekers with an existential danger through different chains of equivalence. As early as 2007, while the Israeli government had just made the decision to grant residency to asylum seekers from Darfur, Sudanese and Eritrean newcomers were connected with grave security threats. A member of the Knesset (MK) and member of the party then heading the government, for instance, claimed during a parliamentary debate on the issue:

$90 \%$ of the infiltrators are not refugees, some of them constitute a security risk, and it is the Israeli government's responsibility to stand for our national interests, our security interests, and to make sure that security threats do not enter [our] border. (MK Plesner, Kadima, Parliamentary Debates on Darfuri Refugees, 2007) 
From the beginning, asylum seekers were thus presented as potentially dangerous subjects intruding onto Israeli territory and threatening Israeli security. Explicitly labelled as threats or as dangerous potential 'terror operatives linked to Al Qaida' (MK Plesner 2007; Foreign Minister Livni, in Wurgaft 2007) they were also securitised through their association with other threats allegedly jeopardising the existence of the state. For instance, Prime Minister Benjamin Netanyahu declared in a 2010 speech on national security:

we must also lay the infrastructure that will prevent the free movement of illegal infiltrators [crossing the borders from Egypt]. We are going to erect an obstacle in the South, as this issue is no less important for our national security than the other things I mentioned [on the topic of national security i.e., Hezbollah and the Iranian threat]. (Prime Minister Netanyahu 2010a)

In addition to putting asylum seekers on an equal footing with two threats painted as existential in the Israeli discourse - Hezbollah and Iran - the notion of 'infiltrator' present in the aforementioned excerpts and commonly used by political actors (and journalists) to designate African migrants is noteworthy. As explained above, the notion of infiltrator was first defined by the Prevention of Infiltration Law, which was itself originally passed to prevent potential Palestinian combatants (fedayeen) from entering Israel in the early 1950s. Using the 'infiltrator' label to designate African asylum seekers and mobilising the Prevention of Infiltration Law to deal with the phenomenon of asylum (occasionally at first and then systematically after 2012) not only contributes to criminalising asylum seekers but also reactivates powerful memories and imaginaries of insecurity, border vulnerability, and terror. It thereby generates a classical securitising modality (Huysmans 2014), where the choices are either acting, or risking that the state dies. As stated by the prime minister two years later, the future and very existence of the country would indeed be at stake:

We must control our borders - it's the duty and right of each country [...]. If over the five years or the decade the country is flooded with hundreds of thousands of illegal refugees, then there will be a real threat to our internal system, to the character of the state and its very future. (Prime Minister Netanyahu 2012b)

Besides the paradoxical association of the 'refugee' category with the notion of 'illegality', the connection of asylum seekers with the notion of a flood threatening the borders acts as another powerful discursive securitising move. The strength of the flood metaphor comes from its multiple dimensions and connotations. The notion of flood both evokes the biblical deluge, hence conveying apocalyptic imageries, and the image of a small isolated and vulnerable island 
(Skilling 2011; Paz 2011). In Israel, which commonly describes itself as a 'villa in the jungle' (Shlaim 2012; Gordon 2011), the flood metaphor performs a very powerful role in the creation of fear, both drawing on and reinforcing the posture of defence and the siege mentality already present in the country. Furthermore, the equation between asylum seekers and a flood reinforces the construction of African migrants as a homogenous existential danger challenging the borders and the existence of Israel. Through this infiltration-flood-asylum seekers equation, asylum seekers are turned from potential refugees into unwanted bodies that need to be blocked without delay.

Overall, the deployment of a storyline framing asylum seekers as a security problem rather than as a human rights question (Huysmans 2000) not only disqualifies the claim that African migrants are potential refugees but also legitimates 'a stronger focus on border controls and a more crucial position of border police' (Huysmans and Squire 2009: 169). In this storyline, the border plays a central and persistent role. On the one hand, the border represents the root cause of Israel's vulnerability and the possibility that dangerous elements enter, for Israel is allegedly 'the only Western country that has a land border with the African continent' (Minister of the Interior Saar, Parliamentary Debates on the Prevention of Infiltration Law, first reading, 2013). On the other hand, the construction of 'infrastructures' at the border permits a reassertion of the role of the border as " "protecting" the "us insiders" from the "them outsiders" ... be it ... armies, criminals, migrants or asylum seekers' (Newman 2003: 14). In such narration, the building of the fence at the border is thus more than just a tool 'that will prevent the free movement of illegal infiltrators' (Prime Minister Netanyahu 2010a): it becomes the means that will protect 'our internal system, the character of the state and its very future' (Prime Minister Netanyahu 2012b).

To a lesser extent, detention technologies participate in creating this imaginary of protection. As explained by the Minister of the Interior during the debates on the amendment of the Prevention of Infiltration Law after the completion of the fence:

The fence alone is not enough. A person who has crossed thousands of kilometres in the desert and had his money taken, that person will cross, even with the fence. There is also a fence within Eretz Israel and illegal Palestinian residents do cross it. The fence is a complementary tool ... Without the closed facility and without the open facilities, they will come. (Minister Saar, Parliamentary Debates on the Prevention of Infiltration Law, second and third readings, 2013)

In this part of the story, the action of the border fence as a frontline expands inside the territory through the use of detention. Detention would play a similar role as the fence itself: it prevents, repels, and blocks the arrival of new asylum seekers onto the territory. 
The infiltrator as a challenge to social order: blocking and controlling undesirable bodies

The second storyline frames asylum seekers as destabilising factors threatening the order of Israeli society. This storyline can be summarised by the following recent declaration of the former Minister of the Interior according to which:

[the presence of illegal immigrants] harms the fabric of Israeli society, damages the labour market, reduces the resources allocated to different sectors such as the education, health care and welfare systems, which Israeli citizens and residents enjoy, and unfortunately, sometimes increases crime in areas where illegal immigrants are concentrated. (Minister of the Interior Erdan, Parliamentary Debates on the Prevention of Infiltration Law, first reading, 2014)

More specifically, two main chains of equivalence can be unravelled in this storyline, both of which appear in this previous statement. The first one associates asylum seekers with the category of crime, fear, and daily insecurity. It is underpinned by the categories of illegality and the repeated assertion according to which 'most of the migrants from Africa are engaged in criminal actions' (Minister of the Interior Yishai, in Haaretz 2012). At a time when demonstrations against the presence of asylum seekers in Southern Tel Aviv (the neighbourhood where most African migrants have settled) were frequent, one member of parliament who himself took part in several demonstrations declared in parliament:

I recently saw the evil that residents of the neighbourhood go through, whose lives become hell. I see a lonely man, and he says: I am afraid to go back to my house, they threaten me, they hurt me, they tell me anti-Semitic things, they beat me. I am going to the police and no one answers me. This is the reality. Can we ignore this reality? (MK Ben Ari, National Union, Parliamentary Debates on the Prevention of Infiltration Law 2012)

The second central chain of equivalence deployed in this storyline articulates asylum seekers as a threat to the Israeli economy and to the job market. As claimed by one member of the Knesset during parliamentary debates:

In hotels ... all the workers, maids and cleaning staff are infiltrators. I am asking: do you not think that this takes the job of an Israeli citizen? (MK Vaknin, Shas, Parliamentary Debates on the Prevention of Infiltration Law 2012)

Framed as a threat to the economy, asylum seekers are not individuals with singular paths, origins, and intentions. Instead, they are 'all infiltrators', or 'labour infiltrators', and constitute 'a flood of migrant workers' (MK Plesner, Parliamentary Debates on Darfuri Refugees 2007), a homogeneous category of undistinguishable subjects menacing the citizens of the state and the social order.

The storyline of asylum seekers as a threat to social order has several effects. First, it casts doubt as to the real motive of African migrants' presence in Israel, 
hence further disqualifying the category of refugee. As claimed by one MK during the 2014 parliamentary debates on the law: 'Why do you not tell the truth: what refugee is there here? After all, they are all job seekers' (MK Zeev, Shas, Parliamentary Debates on the Prevention of Infiltration Law 2014).

Second, similar to the construction of asylum seekers as a national security threat, framing African asylum seekers as 'culpable subjects' (Squire 2009: 107) rather than as people in need of protection enables the speakers to conclude that 'infiltrators' must be managed with police and security measures rather than humanitarian ones. As the then Minister of the Interior Eli Yishai claimed during a radio interview, "most of the African infiltrators are criminals. I would put all of them, without exception, into a prison or other holding facility' (Minister of the Interior Yishai, in Weiler-Polak 2012), because '[w]e must make people feel safe again' (Minister of the Interior Yishai, in Efraim 2015).

Third, addressed through the prism of infiltration, crime, and danger to the job market, asylum seekers are further constructed as undesirable elements that the government must prevent from entering the country through different repelling means. Among these means, reinforcing or in fact sealing the border is again evoked as the key solution to defend Israel from the threatening flood. As the prime minister put it when evoking the decision to construct a fence at the Egyptian border:

During the Winter Session, we will begin the construction of a fence in the South to prevent the massive infiltration of illegal job-seekers, which threaten the character and identity of the state of Israel. This is a necessary step to prevent the country from being flooded by elements that undermine our economy, as well as the unique structure we have built here. (Prime Minister Netanyahu 2010b)

Four years later, while the fence by then completely prevented new asylum seekers from crossing the border, dealing with the 'infiltrators' continued to be intertwined with the imaginary of border protection and border reinforcement. Introducing the amendment of the Prevention of Infiltration Law to the Knesset in 2014, the Minister of the Interior for instance justified the need for the law on the basis that ' $[t]$ he state of Israel has the duty to defend its borders, protect its sovereignty, protect the safety of its citizens and residents' (Minister of the Interior Erdan, Parliamentary Debates on the Prevention of Infiltration Law 2014).

\section{The border as the enactment of national identity}

As mentioned above, the Israeli citizenship regime has first and foremost been designed in order to attract Jewish immigrants to the country. In this context, the presence of non-Jewish migrants has been mostly conceived as a controlled phenomenon aiming to remain temporary and at the margin of the regime 
(Kemp 2010). In instances where the presence of non-Jewish migrants has seemed to endure, political actors and the media alike have been prompt to raise the spectre of the 'demographic threat' jeopardising the Jewish identity of the state (Kritzman-Amir 2009). Therefore, it comes as no surprise that the Jewish character of the state was very quickly part of the public conversation on asylum seekers. Concurrent with the rhetoric of compassion and openness inspired by the experiences of the Jewish people, ${ }^{13}$ the Jewishness of the state was also referred to in a completely different way so as to justify the exclusionary policies in place. Explaining the rationale for improving border protection and the necessity to build a fence at the border, Prime Minister Netanyahu for instance argued:

this phenomenon [the arrival of asylum seekers] is extremely serious and is threatening the various components of society, and of course threatens our national security and our national identity. It began over seven years ago, and when the government took office three years ago, we decided to deal with this problem in all its aspects - first of all, by stopping entries and second, by beginning to send abroad those who are here. If we do not stop their entry, the problem, which now extends to 60,000 infiltrators could easily develop into 600,000, and flood the country, thus eliminating to a large extent our character as a Jewish and democratic state. (Prime Minister Netanyahu 2012a)

Although the identity of the state is here labelled as 'Jewish and democratic', the reference to the demographic issue suggests that the element that needs to be preserved is above all the Jewish dimension of the state. This consideration has been made more explicit in other political statements including those by the Minister of the Interior during the discussions over the Prevention of Infiltration Law, when he stated:

If we decide to be the liberal benchmark in the West, with our own hands, we will lose the only Jewish state that exists. And who denies this simple truth, should just walk around in Bern in Switzerland or in Brussels in Belgium, or Paris and see with his own eyes what happens when countries do not deal on time with the effects of illegal entry into their territory. (Minister of the Interior Saar, Parliamentary Debates on the Prevention of Infiltration Law 2013)

Other than constituting asylum seekers as a threat to national security and to social order, the dominant political discourse in the third storyline thus 'creates an image of immigration associated with an outsider coming inside, as a danger to the homogeneity of the state, the society, and the polity' (Bigo 2002: 67). More than a sheer disruption to the culture of the state, the arrival of the 'other' could turn Israel 'into a country that is not Jewish' (MK Hotovely, Likud, Parliamentary Debate on the Prevention of Infiltration Law 2011), hence potentially leading to the end of the state. Against the imminent danger that the country be wiped out by the waves of 'illegal infiltrators', reinforcing the 
border appears as a central instrument, which political actors insist on normalising through comparisons with other states' experiences and practices. As claimed by one member of parliament during the debates on the Prevention of Infiltration Law, the state of Israel should indeed:

protect its borders, because at the end of the day, this country is a country that we need to protect as a Jewish, democratic state, and that needs to protect its borders like any other Western country in the world. (MK Hasson, Likud, Parliamentary Debate on the Prevention of Infiltration Law 2011)

Acting along the border, the expulsion of 'those who are here' also plays out in this storyline, both bolstering the feeling of vulnerability and the assurance of protection against the threat. Former Minister of the Interior Yishai for instance stated on several occasions that to 'defend the Jewish majority ... each and every one of them [the infiltrators] will return to their countries' (Minister of the Interior Yishai, in Hartman 2011. The border and deportation are thus both constructed in a similar way: as protecting mechanisms enabling the state identity to survive. By excluding and including, these technologies enable membership and delineate the boundaries of belonging, "with the "us" and the "here" being located inside the border while the "other" and the "there" is everything beyond the border' (Newman 2006: 172).

\section{Conclusion}

Under the label of 'illegal infiltrators', African asylum seekers have crystallised all that threatens the state in the Israeli imaginary: the criminal and potential terrorist illegally infiltrating the border, the threat to national security, to the economic order, and to the national identity of the state. The objective of this chapter was to unpack this discourse and more specifically to disentangle the discursive processes by which the exclusionary asylum policies used to manage asylum seekers are justified by political actors. On the basis of a discourse analysis of political speeches and parliamentary debates, I have identified three main storylines framing asylum seekers and the responses to their arrival in different, yet interconnected ways. In the first storyline, asylum seekers are framed as a threat to national security, a threat as perilous and grave as Iran or Hezbollah. Against such a threat, the physical border embodied by the 'fence', the effect of which the detention camps prolong, is presented as a necessary tool to repel 'illegal infiltrators' allegedly threatening the security of the state. In another discursive move, asylum seekers are painted as the conveyors of fear, criminality, and economic threat. In this storyline, asylum seekers are equated both with an external danger, a flood of 'labour infiltrators' that the fence should hold back, and with an internal danger already 'infiltrated' within the country, which detention should contain. Finally, a third storyline of the Israeli political 
discourse constructs asylum seekers as a threat to the Jewish identity of the state, a storyline in which the border and the fence epitomise the demarcation between a dangerous them and a Jewish us.

In this discourse, the different meanings conferred on the border play two connected roles. On the one hand, they reinforce the construction of asylum seekers as a threat to the entire country, its sovereignty, and identity. Associated with the notion of infiltration and flood, the border reinforces the image of a possible demarcation between a safe territory opposed to a dangerous, homogenous external threat to be repelled. On the other hand, the border, sometimes alongside detention and expulsion, also plays out as a shield guaranteeing protection to society, the state, the polity, and its identity. Overall, the border thus operates 'as a meta-concept that condenses a whole set of negative meanings, including illegal immigration ... At the same time [it holds] out the promise of a solution to these hazards' (Walters 2008: 174-5). In a context of disorganised asylum policies in Israel, resorting to the image of border reinforcement not only conveys a sense of fear, but the 'danger of losing control of the borders of the state and of the country's future' (Minister of the Interior Saar, Parliamentary Debates on the Prevention of Infiltration Law 2013), thus justifying the exclusionary policies, but also creating a sense of control, protection, and retrieved sovereignty. Such repeated convocation of the border as central to justifying the exclusionary policies of asylum (even when asylum seekers are no longer crossing the border) stands out against the growing imaginary of liquid or gaseous borders, among academics and practitioners alike (Bigo 2014). In contrast with this dislocated image of the border, the imaginary of closed borders and of the border as a shield remains strong and even at the centre of political discourse in Israel. In spite of the changes that borders have undergone with the development of new technologies (Bigo 2004; Ceyhan 2004; Dillon 2007) and despite the calls in the literature to move 'beyond territoriality' (McNevin 2014), the Israeli case thus suggests that the imaginary of the border as a protection against outsiders, as a way of reclaiming sovereignty and reasserting identity remains central to the political arena.

\section{Notes}

1 Although most African migrants from Sudan and Eritrea are technically not asylum seekers since most of them have not been able to submit a formal asylum request, this chapter applies the notion of asylum seeker to Sudanese and Eritrean migrants since the reason for their presence in Israel is their desire to seek refuge in the country according to the meaning of the Geneva Convention.

2 The metaphor of liquidity refers to a transformation in the 'logic of control and security'. In such an approach of the border 'controls are organized through a series of imperceptible locks and weirs, through a "channelling" of flows, organized in several steps and through various forms of filtering. The idea that borders may be successfully closed or made impermeable is definitely abandoned; walls can always be surmounted, people evade control' (Bigo 2002: 213). 
3 Most migrant workers in Israel come from Thailand, the Philippines, China, Nepal, and Sri Lanka (see: http://hotline.org.il/en/migrants-en/\%e2\%80\%8fcountries-of-origin-ofrefugees-in-israel/).

4 See Hotline for Refugees and Migrants: http://hotline.org.il/en/migrants-en/.

5 As indicated above, this law would later be used to deal with African asylum seekers entering Israel.

6 See on the use and effects of walls Stéphanie Latte Abdallah and Cédric Parizot (2010).

7 Until 2009, Israel in fact delegated the role of questioning, identifying, and determining the status of asylum seekers to the Office of the High Commission for Refugees of the United Nations with the Ministry of Interior having the last say on the decision. After 2009 , the process was taken over by different branches of the Israeli government including the Unit of Identification and Questioning at the Department for Infiltrators and Refugees and the Refugee Status Determination unit.

8 The four asylum seekers recognised as refugees were from Eritrea. Five Sudanese were also granted refugee status but they were already part of the group of Darfuris to whom the government had decided to grant residence permits in 2007.

9 On the changes in asylum policies and detention procedures up until 2013, see Yaron et al. (2013).

10 Between 2008 and 2009, due to the concentration of asylum seekers in southern Tel Aviv, the government attempted to control the settlement of asylum seekers across the territory and started delivering permits valid only in specific areas 'north of Hadera or south of Gadera' (Lijnders 2013: 16). Similarly, in August 2015, after the Supreme Court ruled that asylum seekers detained in Holot for more than twelve months should be released, the government decided that those leaving detention would not be able to resettle in either Eilat or Tel Aviv.

11 The new amendment also introduced new fees to be paid by working 'infiltrators' and their employers.

12 Voluntary return was offered to all asylum seekers wishing to go back to their country, especially to those who were detained in Saharonim and Holot and for whom return was presented as the only possible alternative to detention. When consenting to leave Israel for their own country or a third country, they were offered a fixed amount of money (around $\$ 3,000$ ) and a flight ticket. See on the use of 'voluntary returns', Adi Drori-Avraham et al. (2015).

13 In the first years in particular, those supporting the granting of refugee status to asylum seekers underlined time and again that the Jewish people would 'hold a special obligation' towards the asylum seekers (Kalir 2015:2). For an analysis of the counter-discourse contesting the Israeli asylum policies and on the reference to Jewish history in this discourse, see also Sharon Weinblum (2015).

\section{REFERENCES}

Anteby-Yemini, L., 2009. 'Les «réfugiés soudanais» en Israël: discours, représentations, mobilisations', Maghreb-Machrek 199(1): 71-83.

Bigo, D., 2002. 'Security and Immigration: Toward a Critique of the Governmentality of Unease', Alternatives 27(1): 63-92.

Bigo, D., 2004. 'Global (In)security: The Field of the Professionals of Unease Management and the Ban-opticon', Traces: A Multilingual Series of Cultural Theory 4.

Bigo, D., 2014. 'The (In)Securitization Practices of the Three Universes of EU Border Control: Military/Navy - Border Guards/Police - Database Analysts', Security Dialogue 45(3): 209-25. 
Bigo, D. and E. Guild, 2010. 'The Transformation of European Border Controls', in B. Ryan and V. Mitsilegas, eds, Extraterritorial Immigration Control: Legal Challenges, Leiden: Martinus Nijhoff Publishers.

Ceyhan, A., 2004. 'Sécurité, frontières et surveillance aux Etats-Unis après le 11 septembre 2001', Cultures $\mathcal{E}$ Conflits 53: 113-45.

Dillon, M., 2007. 'Governing Terror: The State of Emergency of Biopolitical Emergence', International Political Sociology 1(1): 7-28.

Doty, R. L., 2003. Anti-Immigrantism in Western Democracies: Statecraft, Desire and the Politics of Exclusion, London: Routledge.

Drori-Avraham, A., S. Rozen and N. Avigal, 2015. 'Where there is no Free Will. Israel's 'Voluntary Return' Procedure for Asylum-seekers'. Hotline for Refugees and Migrants and ASSAF Report. Available at http://hotline.org.il/wp-content/ uploads/2015/04/free-will-web-.pdf (accessed 5 September 2015).

Efraim, O., 2015. Yishai: Next Phase-Arresting Eritrean, Sudanese Migrants. Ynetnews. Available at www.ynetnews.com/articles/0,7340,L-4269540,00.html (accessed 21 October 2015).

Gordon, N., 2011. 'A Villa in the Jungle: The Arab Awakening through the Lens of the Israeli Media', Middle East Law and Governance 3(1-2): 105-17.

Haaretz, 2012. 'Israel's Interior Minister: All African Migrants Should be Jailed', 16 May. Available at www.haaretz.com/israel-news/israel-s-interior-minister-all-africanmigrants-should-be-jailed-1.430800 (accessed 5 September 2015).

Hajer, M. A., 2006. 'Doing Discourse Analysis: Coalitions, Practices, Meaning', in M. Van den Brink and T. Metze, eds, Words Matter in Policy and Planning. Discourse Theory and Method in the Social Sciences, Utrecht: Netherland Geographical Studies.

Hartman, B., 2011. 'Yishai: Every African 'Infiltrator' will Return Home'. Jerusalem Post. Available at www.jpost.com/National-News/Yishai-Every-African-infiltrator-w ill-return-home (accessed 5 September 2015).

Huysmans, J., 2000. 'The European Union and the Securitization of Migration', Journal of Common Market Studies 38(5): 751-77.

Huysmans, J., 2006. The Politics of Insecurity. Fear, Migration and Asylum in the EU, Milton Park/New York: Routledge.

Huysmans, J., 2014. Security Unbound: Enacting Democratic Limits, London: Routledge.

Huysmans, J. and V. Squire, 2009. 'Migration and Security', in M. Dunn Cavelty and V. Mauer, eds, Handbook of Security Studies, London/New York: Routledge.

Jones, R., 2009. 'Checkpoint Security. Gateways, Airports and the Architecture of Security', in K. F. Aas, H. O. Gundhus, and H. M. Lomell, eds, Technologies of InSecurity. The Surveillance of Everyday Life, London: Routledge-Cavendish.

Kalir, B., 2015. 'The Jewish State of Anxiety: Between Moral Obligation and Fearism in the Treatment of African Asylum Seekers in Israel', Journal of Ethnic and Migration Studies 41(4): 580-98.

Kemp, A., 2010. 'Reforming Policies on Foreign Workers in Israel', OECD Social, Employment and Migration Working Papers 103 (19 March 2010).

Kotef, H. and M. Amir, 2011. 'Between Imaginary Lines: Violence and its Justifications at the Military Checkpoints in Occupied Palestine', Theory, Culture \& Society 28(1): 55-80. 
Kritzman-Amir, T., 2009. “"Otherness” as the Underlying Principle in Israel's Asylum Regime', Israel Law Review 42(03): 603-27.

Latte Abdallah, S. and C. Parizot, 2010. A l'ombre du Mur: Israéliens et Palestiniens entre séparation et occupation, Paris: Actes Sud.

Law of Return, 1950. Available at https://knesset.gov.il/laws/special/eng/return.htm (accessed 1 July 2015).

Law on Citizenship, 1952. Available at www.israellawresourcecenter.org/israellaws/fulltext/nationalitylaw.htm (accessed 1 July 2015).

Lijnders, L., 2013. 'Do Not Send Us So We Can Become Refugees Again. African Refugee Development Center and Hotline for Migrant Workers Report', February 2013. Available at http://hotline.org.il/wp-content/uploads/ARDC_HMW_ SouthSudanReport031913_Eng.pdf (accessed 5 September 2015).

Lior, I., 2015. 'Israel Has Granted Refugee Status to Only Four Sudanese and Eritrean Asylum Seekers'. Haaretz. Available at www.haaretz.com/israel-news/. premium-1.643134 (accessed 5 September 2015).

Lustick, I., 1980. Arabs in the Jewish State: Israel's Control of a National Minority, Austin, TX: University of Texas Press.

McNevin, A., 2014. 'Beyond Territoriality: Rethinking Human Mobility, Border Security and Geopolitical Space from the Indonesian Island of Bintan', Security Dialogue 45(3): 295-310.

Newman, D., 2003. 'On Borders and Power: A Theoretical Framework', Journal of Borderlands Studies 18(1): 13-25.

Newman, D., 2006. 'Borders and Bordering towards an Interdisciplinary Dialogue', European Journal of Social Theory 9(2): 171-86.

Parliamentary Debates on the Failure to Manage Darfuri Refugees, 2007. Knesset Protocols, 17 October (in Hebrew).

Parliamentary Debates on the Prevention of Infiltration Law, 2011. First Reading. Knesset Protocols, 28 March (in Hebrew).

Parliamentary Debates on the Prevention of Infiltration Law, 2012. Second and Third Readings. Knesset Protocols, 9 January (in Hebrew).

Parliamentary Debates on the Prevention of Infiltration Law, 2013. First Reading. Knesset Protocols, 25 November (in Hebrew).

Parliamentary Debates on the Prevention of Infiltration Law, 2014. First Reading. Knesset Protocols, 1 December (in Hebrew).

Parsons, N. and M. B. Salter, 2008. 'Israeli Biopolitics: Closure, Territorialisation and Governmentality in the Occupied Palestinian Territories', Geopolitics 13(4): 701-24.

Paz, Y., 2011. 'Ordered Disorder: African Asylum Seekers in Israel and Discursive Challenges to an Emerging Refugee Regime'. Research Paper 205 UNHCR.

Prevention of Infiltration Law, 1954. Available at http://israellawresourcecenter. org/emergencyregs/fulltext/preventioninfiltrationlaw.htm (accessed 15 July 2015).

Prevention of Infiltration Law, 2012. Amendment 3 and Temporary Order. Available at www.knesset.gov.il/privatelaw/data/18/3/577_3_2.rtf (in Hebrew, accessed 29 October 2015). 
Prevention of Infiltration Law, 2013. Amendment 4 and Temporary Order. Available at www.knesset.gov.il/privatelaw/data/19/3/817_3_1.rtf (in Hebrew, accessed 29 October 2015).

Prevention of Infiltration Law, 2014. Amendments and Temporary Order. Available at knesset.gov.il/privatelaw/data/19/3/904_3_1.rtf (in Hebrew, accessed 29 October 2015).

Prime MinisterNetanyahu, 2010a. Address at the National Security CollegeCommencement Ceremony, 27 July. Available at http://pmo.govil/English/MediaCenter/Speeches/ Pages/speechmabal270710.aspx (accesed 5 September 2015).

Prime Minister Netanyahu, 2010b. Opening Session of the Knesset. Knesset Protocols, 11 October.

Prime Minister Netanyahu, 2012a. Special meeting at Ammunition Hill, 20 May. Available at http://pmo.gov.il/MediaCenter/SecretaryAnnouncements/Pages/ govmes200512.aspx (in Hebrew) (accessed 1 July 2015).

Prime Minister Netanyahu, 2012b. Speech on the Israeli patrol at the Egypt-Israel border, 27 March. Available at http://www.pmo.gov.il/MediaCenter/Speeches/Pages/ speechGvul270312.aspx (in Hebrew) (accessed 1 July 2015).

Refugees' Rights Forum, 2008. 'The Detention of Asylum Seekers and Refugees'. Policy Paper, June 2008. Available at http://hotline.org.il/wp-content/uploads/ RefugeeRightsForumDetention.pdf (accessed 18 July 2016).

Salter, M. B., 2008. 'When the Exception Becomes the Rule: Borders, Sovereignty, and Citizenship', Citizenship Studies 12(4): 365-80.

Saussure, F., 2002. Ecrits de linguistique générale, Paris: Gallimard.

Shafir, G., 1984. 'Changing Nationalism and Israel's “Open Frontier” on the West Bank', Theory and Society 13(6): 803-27.

Shani, E., S. Ayal, Y. Berman, and S. Rozen, 2014. 'No Safe Haven. Israeli Asylum Policy as Applied to Eritrean and Sudanese Citizens'. Hotline for Refugees and Migrants Report, October 2014. Available at http://hotline.org.il/wp-content/uploads/ No-Safe-Haven.pdf (accessed 1 July 2015).

Shlaim, A., 2012. 'Israel, America, and Arab Democracy'. Paper presented at the workshop ‘Israel a Democracy under Stress?’, ULB, 15 March 2012.

Skilling, P., 2011. 'Immigration Policy in New Zealand: Divergent Narratives, Shared Assumptions and National Identity'. Paper presented at the 6th Interpretative Policy Analysis Conference, 23-25 June 2011.

Squire, V., 2009. The Exclusionary Politics of Asylum, Basingstoke/New York: Palgrave Macmillan.

Walters, W., 2006. 'Border/Control', European Journal of Social Theory 9(2): 187-203.

Walters, W., 2008. 'Putting the Migration-Security Complex in its Place', in L. Amoore and M. De Goede, eds, Risk and the War on Terror, New York/London: Routledge.

Weiler-Polak, D., 2012. 'Threats Made Against South Tel Aviv Aid Workers after Yishai Remarks'. Haaretz, 17 May 2012 Available at www.haaretz.com/israel-news/ threats-made-against-south-tel-aviv-aid-workers-after-yishai-remarks-1.430920 (accessed 29 October 2015).

Weinblum, S., 2015. 'Managing the Borders, Governing the Other: The Construction of Asylum Seekers in Israeli Political Discourses'. Paper written for the 2015 OMSS conference, University of Oxford, 15-16 May 2015. 
Willen, S. S., 2010. 'Darfur through the Lens of the Shoah', in B. Good, M. Fischer, S. S. Willen, and M.-J. Del Vecchio Good, eds, A Reader in Medical Anthropology, Oxford: Wiley Blackwell.

Wurgaft, N., 2007. 'In Face of Criticism, Foreign Min. Campaign to Explain Refugee Policy'. Haaretz, 30 August 2007.

Yaron, H., N. Hashimshony-Yaffe, and J. Campbell, 2013. “ “Infiltrators” or Refugees? An Analysis of Israel's Policy Towards African Asylum-Seekers', International Migration 51(4): 144-57. 